JURNAL KETAHANAN NASIONAL

Vol. 26, No. 1, April 2020, Hal 23-39

DOI:http://dx.doi.org/ 10.22146/jkn.54415

ISSN:0853-9340(Print), ISSN:2527-9688(Online)

Online sejak 28 Desember 2015 di :http://jurnal.ugm.ac.id/JKN

VOLUME 26

No. 1, April 2020

Halaman 23-39

\title{
Kondisi Kerentanan dan Ketahanan Masyarakat Terhadap Bencana Tanah Longsor di Desa Pagerharjo, Kecamatan Samigaluh, Kabupaten Kulonprogo, Yogyakarta
}

\author{
Dina Ruslanjari \\ Universitas Gadjah Mada, Yogyakarta \\ email: dienarus@ugm.ac.id \\ Resi Sadewa Permana \\ Universitas Gadjah Mada, Yogyakarta \\ email: resi.sadewa@mail.ugm.ac.id \\ Fatimah Wardhana \\ Universitas Gadjah Mada, Yogyakarta \\ email: fatimah.wrdn@mail.ugm.ac.id
}

\begin{abstract}
Kulonprogo is a regency with a high level of vulnerability to landslides disaster. The areas with high vulnerability include Pagerharjo Village, especially West Nglinggo and East Nglinggo sub-villages. This study aims (1) to analyze the social, economic, physical, and environmental vulnerability to landslides disaster in the community of East Nglinggo and West Nglinggo sub-villages, (2) to assess the vulnerability to landslides disaster for the community in West Nglinggo and East Nglinggo sub-villages, and (3) to analyze the community resilience in West Nglinggo and East Nglinggo sub-village to landslides disaster.

This research was a quantitative research with survey method. The study population came from the heads of households in West Nglinggo and East Nglinggo sub-villages. The technique for determining the sample is using the purposive sampling. Statistical descriptive analysis is used to analyze the community's vulnerability to landslides disaster in social, economic, physical, and environmental aspects.

The results showed that: (1) The community in West Nglinggo and East Glinggo sub-villages, more than a half of them has a moderate category for social vulnerability, moderate category for economic vulnerability, moderate category for physical vulnerability, and high category for environmental vulnerability, (2) More than half of the people in West Nglinggo sub-village and East Nglinggo sub-village are included in the high category, (3) while the community resilience in East Nglinggo sub village and West Nglinggo sub village to landslides disaster is in low category.
\end{abstract}

Keywords: Landslides Disaster, Vulnerability, Community Resilience.

\begin{abstract}
ABSTRAK
Kulonprogo merupakan wilayah dengan tingkat kerentanan yang tinggi terhadap bencana tanah longsor. Wilayah dengan tingkat kerawanan yang tinggi di antaranya adalah Desa Pagerharjo, khususnya di Dusun Nglinggo Barat dan Nglinggo Timur. Penelitian ini bertujuan untuk: (1) menganalisis kerentanan masyarakat terhadap bencana tanah longsor pada aspek sosial, ekonomi, fisik, dan lingkungan di Dusun Nglinggo Barat dan Nglinggo Timur; (2)
\end{abstract}


menilai kerentanan masyarakat di Dusun Nglinggo Barat dan Nglinggo Timur terhadap bencana tanah longsor; dan (3) menganalisis ketahanan masyarakat Dusun Nglinggo Barat dan Nglinggo Timur terhadap bencana tanah longsor.

Penelitian ini merupakan penelitian kuantitatif dengan metode survei. Populasi penelitian berasal dari kepala rumah tangga di Dusun Nglinggo Barat dan Nglinggo Timur. Teknik penentuan sampel menggunakan metode purposive sampling. Analisis deskriptif statistik digunakan untuk menganalisis kerentanan pada aspek-aspek sosial, ekonomi, fisik, dan lingkungan, serta ketahanan masyarakat terhadap bencana tanah longsor.

Hasil penelitian menunjukkan bahwa : (1) Masyarakat Dusun Nglinggo Barat dan Nglinggo Timur lebih dari separuhnya mempunyai kerentanan sosial kategori sedang; kerentanan ekonomi kategori sedang; kerentanan fisik kategori sedang; dan kerentanan lingkungan kategori tinggi. (2) Lebih dari separuh masyarakat Dusun Nglinggo Barat dan Dusun Nglinggo Timur termasuk kategori kerentanan tinggi. (3) Ketahanan masyarakat di Dusun Nglinggo Barat dan Dusun Nglinggo Timur terhadap bencana tanah longsor termasuk dalam kategori rendah.

\section{Kata Kunci: Bencana Tanah Longsor, Kerentanan, Ketahanan Masyarakat.}

\section{PENGANTAR}

Indonesia merupakan salah satu negara yang rawan terhadap berbagai macam bencana. Berdasarkan Data dan Informasi Bencana Indonesia (DIBI) dari Badan Nasional Penanggulangan Bencana (BNPB, 2019), bencana tanah longsor merupakan bencana dengan frekuensi kejadian terbesar ketiga di Indonesia. BNPB menyebutkan bahwa presentase urutan kejadian bencana terbesar, yaitu: banjir sebesar 33\%, puting beliung sebesar 23\%, tanah longsor sebesar 19\%, kebakaran sebesar 9\%, kekeringan sebesar $7 \%$, dan sisanya berbagai macam bencana lainnya. Gambar 1 menunjukkan diagram perbandingan jumlah kejadian bencana di Indonesia dari tahun 2000 hingga bulan Oktober 2019.

Hadmoko dkk. (2010) menjelaskan bahwa korban jiwa yang disebabkan oleh bencana tanah longsor di Pulau Jawa saja sudah sangatlah tinggi, karena tingginya frekuensi kejadian bencana tanah longsor dan tingginya kerentanan masyarakat. Berdasarkan data dari DIBI BNPB (2019), bahwa kurang dari sepuluh tahun terakhir telah terjadi 30 kejadian bencana tanah longsor di Kabupaten Kulonprogo. Berdasarkan jumlah kejadian tersebut menunjukkan bahwa Kabupaten Kulonprogo merupakan salah satu wilayah kabupaten di Pulau Jawa yang sering mengalami kejadian bencana tanah longsor.

Berdasarkan hasil survei awal, diketahui bahwa terdapat 5 (lima) dusun yang termasuk dalam kategori kerawanan tinggiterhadap bencana tanah longsor di Desa Pagerharjo, yaitu: Dusun Mendolo, Nglinggo Barat, Nglinggo Timur, Sarigono, dan Separang. Kampung Siaga Bencana (KSB) juga telah dibentuk di Desa Pagerharjo. Salah satu tujuan dibentuknya KSB Desa Pagerharjo adalah untuk menyiapkan ketahanan masyarakat menghadapi bencana tanah longsor yang terjadi di wilayah desa tersebut.

Dusun Nglinggo Barat dan Nglinggo Timur dipilih sebagai lokasi penelitian, karena kedua dusun tersebut merupakan daerah dengan tingkat kerawanan bencana tanah longsor paling tinggi. Pada kedua dusun tersebut juga merupakan tempat kejadian bencana tanah longsor tahun 2017, yang mengakibatkan seorang warga meninggal dunia, terjadinya kerusakan rumah, dan kematian ternak warga. Di samping itu, Dusun Nglinggo Barat dan Nglinggo Timur juga merupakan kawasan wisata dengan objek wisata berupa Wisata Edukasi Kehidupan Masyarakat Desa, yaitu Wisata Kebun Teh, Bukit Ngisis, dan Air Terjun. Kondisi Dusun Nglinggo Barat dan Nglinggo Timur sebagai 
Dina Ruslanjari, Resi Sadewa Permana, Fatimah Wardhana -- Kondisi Kerentanan dan Ketahanan Masyarakat Terhadap Bencana Tanah Longsor di Desa Pagerharjo, Kecamatan Samigaluh, Kabupaten Kulonprogo, Yogyakarta

Gambar 1

Perbandingan Jumlah Kejadian Bencana di Indonesia

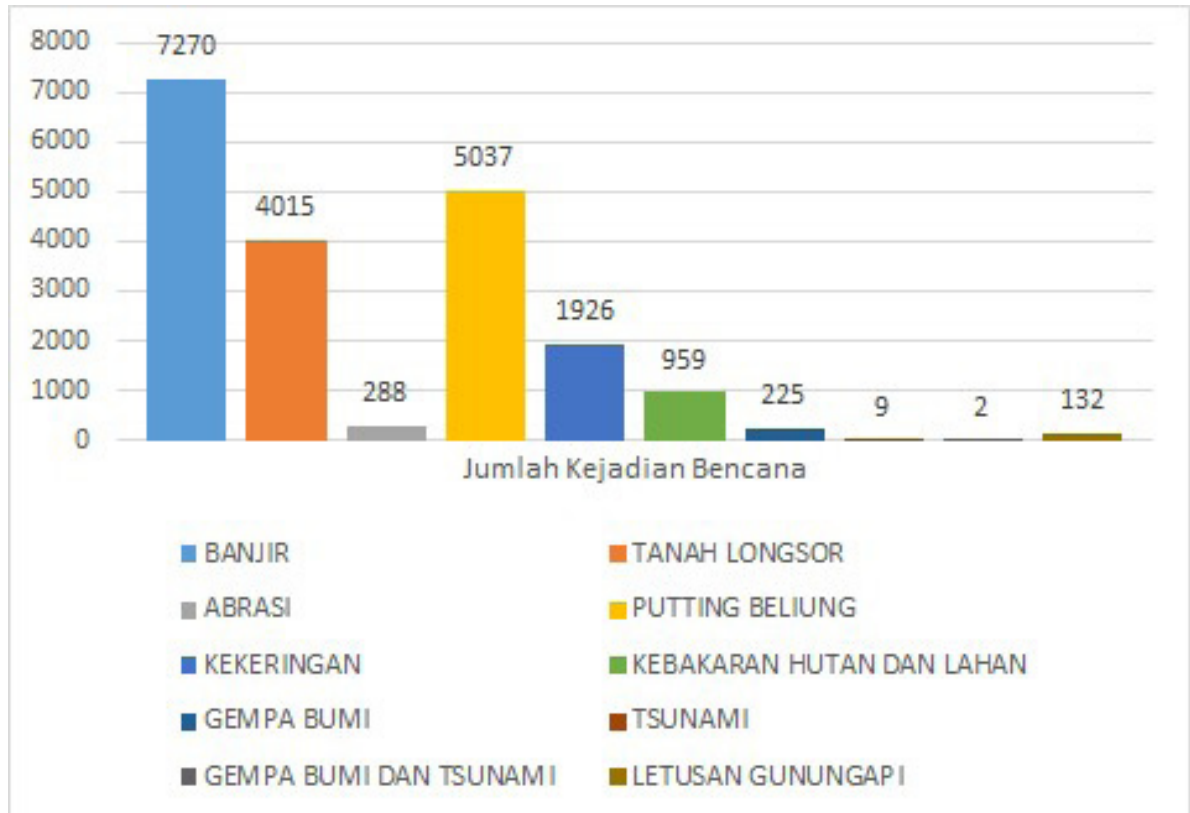

Sumber: BNPB, 2019

kawasan wisata menyebabkan bertambahnya elemen berisiko terhadap bencana tanah longsor, yaitu banyaknya wisatawan yang berkunjung ke kedua dusun tersebut. Pengembangan kedua dusun sebagai daerah wisata juga harus dilakukan dengan tepat agar tidak meningkatkan kerentanan terhadap bencana tanah longsor.

Kerentanan adalah suatu kondisi dari suatu komunitas atau masyarakat yang mengarah atau menyebabkan ketidakmampuan dalam menghadapi ancaman bencana (PERKA BNPB Nomor 3 Tahun 2012). Kerentanan merupakan suatu kondisi yang ditentukan oleh faktor atau proses dari sosial, ekonomi, fisik, dan lingkungan, sehingga dapat meningkatkan kelemahan masyarakat dalam menghadapi dampak dari bencana (UN/ISDR, 2004; UNU, 2004; Thywissen, 2006). Ketahanan menurut Twigg (2007) mencakup tiga pengertian, yaitu: (a) kapasitas untuk menyerap tekanan atau kekuatan-kekuatan yang menghancurkan, melalui perlawanan atau adaptasi; (b) kapasitas untuk mengelola atau memertahankan fungsifungsi dan struktur dasar tertentu, selama kejadian-kejadian yang mendatangkan bencana atau malapetaka; dan (c) kapasitas untuk memulihkan diri atau 'melenting balik' setelah suatu kejadian.

Ketahanan masyarakat adalah kemampuan untuk mengelola bencana, melalui proses adaptasi, mempertahankan fungsi-fungsi dasar di dalam masyarakat yang menentukan keberlanjutan kehidupan, serta kemampuan untuk memulihkan diri kepada keadaan semula (Softani, 2016). Masyarakat yang tahan terhadap bencana meliputi: (a) kapasitas komunitas untuk dapat mengurangi terhadap risiko/ kerusakan melalui mitigasi ataupun adaptasi; (b) kapasitas untuk mempertahankan fungsi-fungsi dasar dan struktur di dalam keadaan bencana; (c) kapasitas untuk memulihkan diri pasca kejadian bencana. Hal tersebut meliputi 
ketahanan/ resiliensi yang tercipta karena kapasitas masyarakat maupun karakter yang mendukung ketahanan masyarakat (Twigg, 2007).

Bencana tanah longsor merupakan pergerakan material pada lereng yang turun dan keluar dari lereng akibat dari pengaruh gravitasi (Van Westen dkk., 2011). Hardiyatmo (2012) menambahkan bahwa gerakan massa yang meluncur ke bawah dari material pembentuk lereng dapat berupa tanah, batu, tanah timbunan atau campuran dari material lain, dan apabila gerakan massa tanah sangat berlebihan, maka disebut tanah longsor (landslide).

Penelitian ini mempunyai tujuan:(1) menganalisis kerentanan sosial, ekonomi, fisik, dan lingkungan masyarakat terhadap bencana tanah longsor di Dusun Nglinggo Timur dan Nglinggo Barat; (2) menilai kerentanan masyarakat di Dusun Nglinggo
Barat dan Nglinggo Timur terhadap bencana tanah longsor; dan (3) menganalisis ketahanan Dusun Nglinggo Barat dan Dusun Nglinggo Timur terhadap tanah longsor.

Penelitian ini dilakukan di Dusun Nglinggo Barat dan Nglinggo Timur, Desa Pagerharjo, Kecamatan Samigaluh, Kabupaten Kulonprogo. Kedua dusun tersebut dipilih karena masuk dalam kategori tingkat kerawanan bencana tanah longsor yang tinggi, namun belum ada informasi mengenai kondisi kerentanan dan ketahanan masyarakat dalam menghadapi bencana tanah longsor. Jenis penelitian ini adalah penelitian kuantitatif dengan menggunakan metode survei untuk proses perolehan data.

Populasi penelitian ini berasal dari kepala keluarga di Dusun Nglinggo Barat dan Nglinggo Timur. Teknik penentuan sampel adalah purposive sampling. Teknik penentuan jumlah sampel penelitian ini

Tabel 1

Kesesuaian antara Tujuan dengan Variabel Penelitian

\begin{tabular}{|c|c|c|c|}
\hline Tujuan & Variabel Terikat & Variabel Bebas & Analisis Data \\
\hline $\begin{array}{l}\text { Menganalisis kerentanan sosial, } \\
\text { ekonomi, fisik, dan lingkungan } \\
\text { masyarakat terhadap bencana tanah } \\
\text { longsor di Dusun Nglinggo Barat } \\
\text { dan Nglinggo Timur }\end{array}$ & $\begin{array}{l}\begin{array}{l}\text { Kerentanan } \\
\text { ekonomi }\end{array} \\
\text { Kerentanan fisik } \\
\text { Kerentanan } \\
\text { lingkungan }\end{array}$ & $\begin{array}{l}\text { Tingkat pendidikan } \\
\text { Tingkat kelompok rentan } \\
\text { Tingkat nilai sosial } \\
\text { Tingkat hubungan social } \\
\text { Sumber penghidupan } \\
\text { Tingkat pendapatan } \\
\text { Tingkat pemenuhan kehidupan } \\
\text { Material rumah } \\
\text { Halaman rumah } \\
\text { Keberadaan penahan tebing } \\
\text { Kondisi jalur evakuasi }\end{array}$ & $\begin{array}{l}\text { Statistik } \\
\text { Deskriptif }\end{array}$ \\
\hline $\begin{array}{l}\text { Menilai kerentanan masyarakat } \\
\text { di Dusun Nglinggo Barat dan } \\
\text { Nglinggo Timur }\end{array}$ & $\begin{array}{l}\text { Kerentanan } \\
\text { Masyarakat }\end{array}$ & $\begin{array}{l}\text { Kerentanan sosial } \\
\text { Kerentanan ekonomi } \\
\text { Kerentanan fisik } \\
\text { Kerentanan lingkungan }\end{array}$ & $\begin{array}{l}\text { Statistik } \\
\text { Deskriptif }\end{array}$ \\
\hline $\begin{array}{l}\text { Menganalisis ketahanan } \\
\text { masyarakat terhadap tanah longsor } \\
\text { berdasarkan nilai kerentanan } \\
\text { di Dusun Nglinggo Barat dan } \\
\text { Nglinggo Timur }\end{array}$ & $\begin{array}{l}\text { Kapasitas } \\
\text { Masyarakat }\end{array}$ & $\begin{array}{l}\text { Kapasitas sosial } \\
\text { Kapasitas ekonomi } \\
\text { Kapasitas fisik } \\
\text { Kapasitas lingkungan }\end{array}$ & Deskriptif \\
\hline
\end{tabular}

Sumber: (UN/ISDR, 2004; UNU, 2004; Thywissen, 2006). 
Dina Ruslanjari, Resi Sadewa Permana, Fatimah Wardhana -- Kondisi Kerentanan dan Ketahanan Masyarakat Terhadap Bencana Tanah Longsor di Desa Pagerharjo, Kecamatan Samigaluh, Kabupaten Kulonprogo, Yogyakarta

menggunakan rumus Isaac dan Michael dengan derajat kesalahan $10 \%$ yang disebutkan oleh Sugiyono (2013). Penentuan proporsi sampel dalam penelitian ini menggunakan hasil dari modifikasi rumus yang disebutkan oleh Kumar (2005). Berdasarkan perhitungan dari kedua rumus tersebut, maka jumlah sampel responden untuk Dusun Nglinggo Barat sebanyak 25 responden, dan jumlah sampel untuk Dusun Nglinggo Timur sebanyak 22 responden. Variabel dalam penelitian ini terdiri atas 4 (empat) variabel terikat, yakni: kerentanan sosial, ekonomi, fisik dan, lingkungan masyarakat. Tabel 1 menunjukkan kesesuaian antara tujuan penelitian dengan variabel penelitian.

Berdasarkan perhitungan dari keseluruhan variabel terikat, maka kategori kerentanan masyarakat dapat diperoleh. Thywissen (2006) menyatakan bahwa kerentanan dapat dinyatakan sebagai derajat kerusakan dari elemen berisiko atau hasil dari terjadinya suatu fenomena alam dengan kekuatan tertentu yang dapat ditunjukkan dengan skala 0 hingga 1 . Kelas indeks kerentanan masyarakat pada penelitian ini ditunjukkan oleh Tabel 2.

Tabel 2

Klasifikasi Indeks Kerentanan Masyarakat

\begin{tabular}{ll}
\hline Kelas Kerentanan & Skor / Indeks \\
\hline Rendah & $0-0,333$ \\
Sedang & $0,334-0,667$ \\
Tinggi & $0,668-1$ \\
\hline
\end{tabular}

Sumber: PERKA BNPB No. 2 (2012)

Teknik pengumpulan data pada penelitian ini menggunakan instrumen penelitian kuesioner. Kuesioner disusun dalam bentuk pilihan ganda sesuai dengan variabel bebas penelitian. Teknik skoring digunakan pada setiap item jawaban responden pada kuesioner. Pendampingan pengisian kuesioner dilakukan untuk menghindari kesalahan dalam pengisian kuesioner. Teknik analisis statistik deskriptif digunakan dalam menganalisis kerentanan masyarakat dan membandingkan kerentanan pada Dusun Nglinggo Barat dan Nglinggo Timur.

\section{PEMBAHASAN}

\section{Kerentanan Sosial Masyarakat}

Kerentan sosial masyarakat merupakan variabel terikat yang diperoleh dari 4 variabel bebas. Variabel bebas tersebut terdiri dari tingkat pendidikan, tingkat kelompok rentan, nilai sosial, dan hubungan sosial. Instrumen penelitian berupa kuesioner digunakan untuk mendapatkan data tentang kerentanan sosial masyarakat. Tingkat pendidikan dalam penelitian ini terdiri dari: kerentanan kelas rendah yakni perguruan tinggi; kerentanan kelas sedang yakni SMP atau SMA; dan kerentanan kelas tinggi yakni tidak sekolah, tidak lulus SD, atau SD. Pengetahuan seseorang dipengaruhi oleh faktor sosial ekonomi, kultur (budaya dan agama), pendidikan dan pengalaman seseorang (Notoatmodjo, 2007; Riyanto, 2015).

Hasil analisis kuesioner penelitian tentang tingkat pendidikan di Dusun Nglinggo Barat menunjukkan bahwa 32\% masyarakat merupakan masyarakat dengan tingkat pendidikan berupa SMP dan atau SMA dan 68\% merupakan masyarakat dengan tingkat pendidikan tidak sekolah, atau tidak lulus SD, atau SD. Hasil analisis kuesioner penelitian di Dusun Nglinggo Timur menunjukkan bahwa 9\% masyarakat merupakan masyarakat dengan tingkat pendidikan perguruan tinggi, 50\% merupakan masyarakat dengan tingkat pendidikan SMP dan atau SMA, dan $41 \%$ merupakan masyarakat tidak sekolah, tidak lulus SD, dan atau SD (Gambar 2). 
Gambar 2

Persentase Tingkat Pendidikan Masyarakat

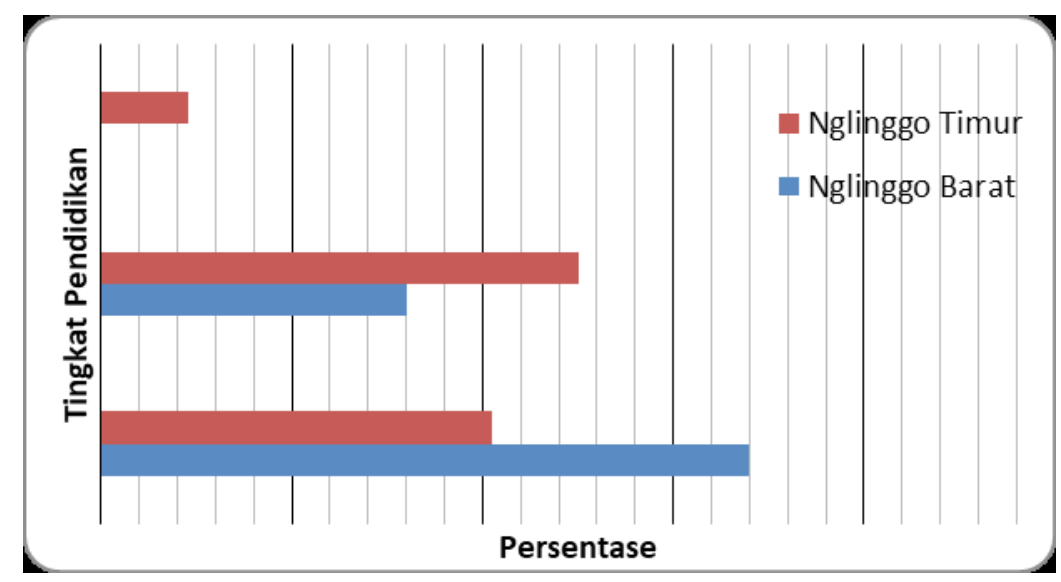

Sumber: Analisis Data Primer 2019

Gambar 3

Persentase Tingkat Kelompok Rentan

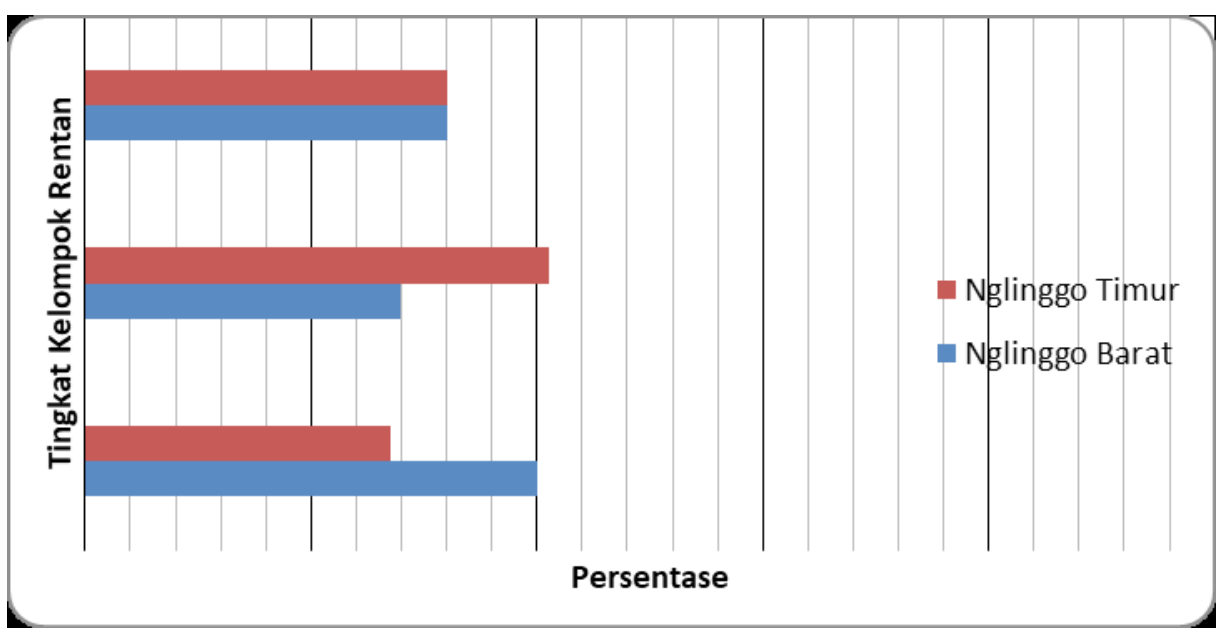

Sumber: Analisis Data Primer 2019

Kelompok rentan dalam penelitian ini merupakan kelompok masyarakat yang rentan dalam menghadapi kejadian bencana tanah longsor. Kelompok rentan terdiri dari balita, ibu hamil, ibu menyusui, masyarakat yang mempunyai kebutuhan khusus atau difabel, dan lansia. Tingkat kelompok rentan dalam penelitian ini terbagi menjadi tiga tingkatan yaitu: kerentanan kelas rendah yakni tidak ada anggota kelompok rentan dalam satu keluarga, kerentanan kelas sedang yakni seorang anggota kelompok rentan dalam satu keluarga, dan kerentanan kelas tinggi yani lebih dari seorang anggota kelompok rentan dalam satu keluarga.

Hasil analisis kuesioner penelitian mengenai tingkat kelompok rentan di Dusun Nglinggo Barat menunjukkan bahwa 32\% masyarakat tidak mempunyai anggota kelompok rentan, 28\% masyarakat mempunyai seorang anggota kelompok rentan, dan 40\% masyarakat mempunyai lebih dari seorang anggota kelompok rentan. Hasil analisis kuesioner penelitian di Dusun Nglinggo 
Dina Ruslanjari, Resi Sadewa Permana, Fatimah Wardhana -- Kondisi Kerentanan dan Ketahanan Masyarakat Terhadap Bencana Tanah Longsor di Desa Pagerharjo, Kecamatan Samigaluh,

Kabupaten Kulonprogo, Yogyakarta

Timur menunjukkan bahwa 32\% masyarakat tidak mempunyai anggota kelompok rentan, $41 \%$ masyarakat mempunyai seorang anggota kelompok rentan, dan $27 \%$ masyarakat mempunyai lebih dari seorang anggota kelompok rentan. Gambar 3 merupakan persentase tingkat kelompok rentan di Dusun Nglinggo Barat dan Nglinggo Timur.

Nilai Sosial dalam penelitian ini merupakan variabel bebas penentu kerentanan sosial yang diperoleh berdasarkan faktor penentu nilai sosial, yaitu tingkat kepercayaan antar tetangga dan tingkat pertisipasi dalam kegiatan budaya. Klasifikasi tingkat nilai sosial terdiri dari: kerentanan kelas rendah yakni baik; kerentanan kelas sedang yakni cukup; dan kerentanan kelas tinggi yakni kurang. Hasil analisis kuesioner penelitian mengenai tingkat nilai sosial di Dusun Nglinggo Timur menunjukkan bahwa 64\% masyarakat mempunyai nilai sosial yang baik dan 36\% masyarakat mempunyai nilai sosial yang cukup. Hasil analisis kuesioner penelitian di Dusun Nglinggo Timur menunjukkan bahwa $73 \%$ masyarakat mempunyai nilai sosial yang baik, $23 \%$ masyarakat mempunyai nilai sosial yang cukup, dan 4\% masyarakat mempunyai nilai sosial yang kurang. Gambar
4 merupakan persentase tingkat nilai sosial di Dusun Nglinggo Barat dan Nglinggo Timur.

Hubungan sosial dalam penelitian ini merupakan variabel bebas penentu kerentanan sosial diperoleh berdasarkan empat faktor penentu hubungan sosial, yakni pengalaman mendapatkan bantuan dari tetangga, pengalaman mendapatkan bantuan dari kerabat atau keluarga, tingkat partisipasi dalam acara keagamaan, dan tingkat partisipasi dalam penjagaan keamanan. Klasifikasi hubungan sosial terdiri dari: kerentanan kelas rendah yakni baik; kerentanan kelas sedang yakni cukup; dan kerentanan kelas tinggi yakni kurang. Hasil analisa kuesioner penelitian mengenai tingkat hubungan sosial di Dusun Nglinggo Barat menunjukkan bahwa $12 \%$ masyarakat mempunyai hubungan sosial yang baik dan $88 \%$ masyarakat mempunyai hubungan sosial yang cukup. Hasil analisis kuesioner penelitian di Dusun Nglinggo Timur menunjukkan bahwa $91 \%$ masyarakat mempunyai hubungan sosial yang cukup dan $9 \%$ masyarakat mempunyai hubungan sosial yang kurang.

Berdasarkan hasil dari analisis dari tingkat pendapatan, tingkat kelompok rentan, tingkat nilai sosial, dan tingkat hubungan sosial, diketahui bahwa 56\% masyarakat Dusun

Gambar 4

Persentase Tingkat Nilai Sosial

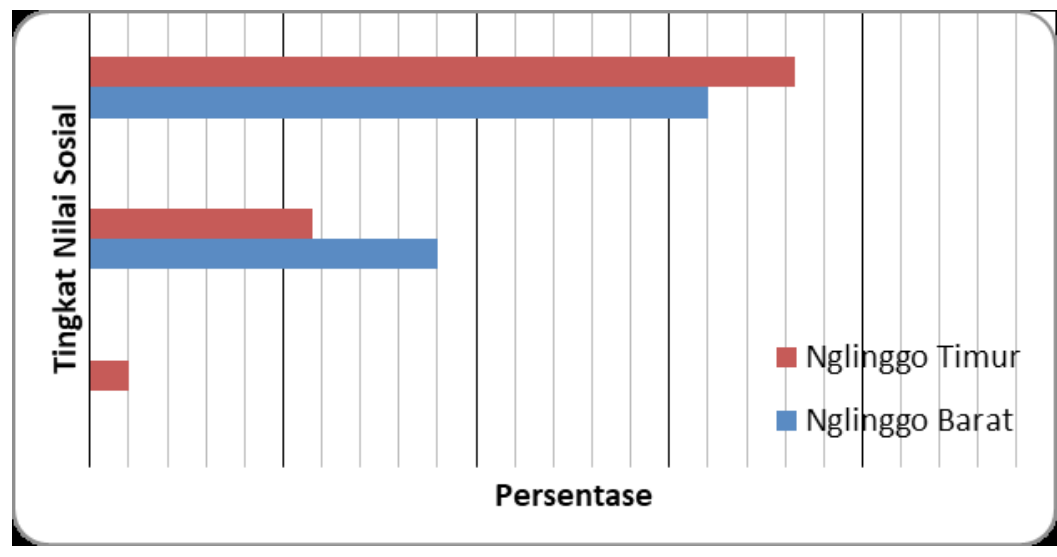

Sumber: Analisis Data Primer 2019 
Gambar 5

Presentase Tingkat Hubungan Sosial

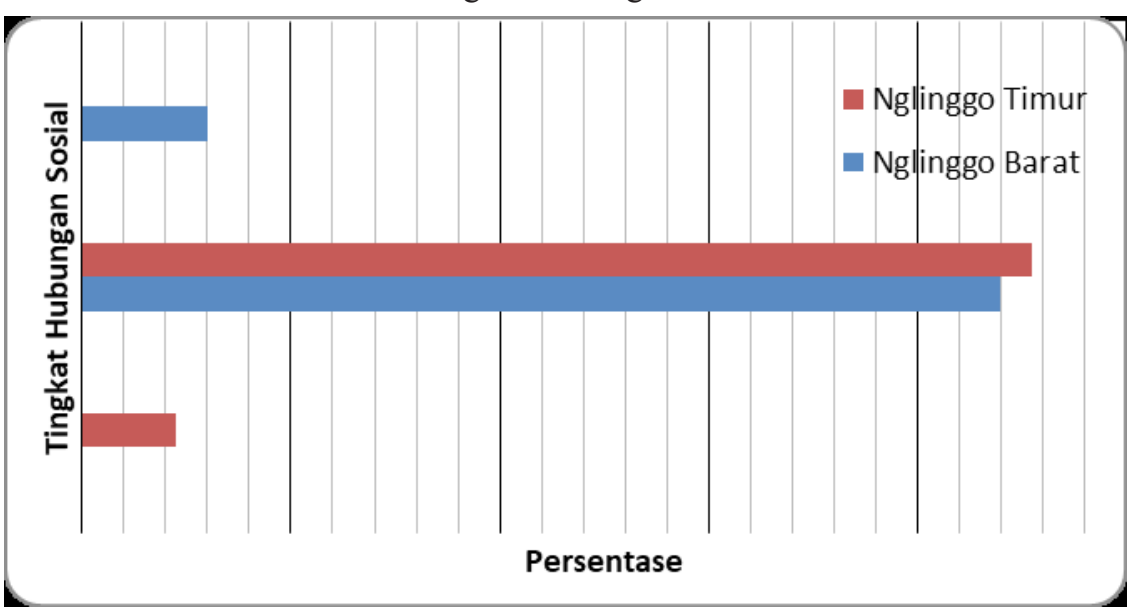

Sumber: Analisis Data Primer 2019

Gambar 6

Presentase Kerentanan Sosial Masyarakat

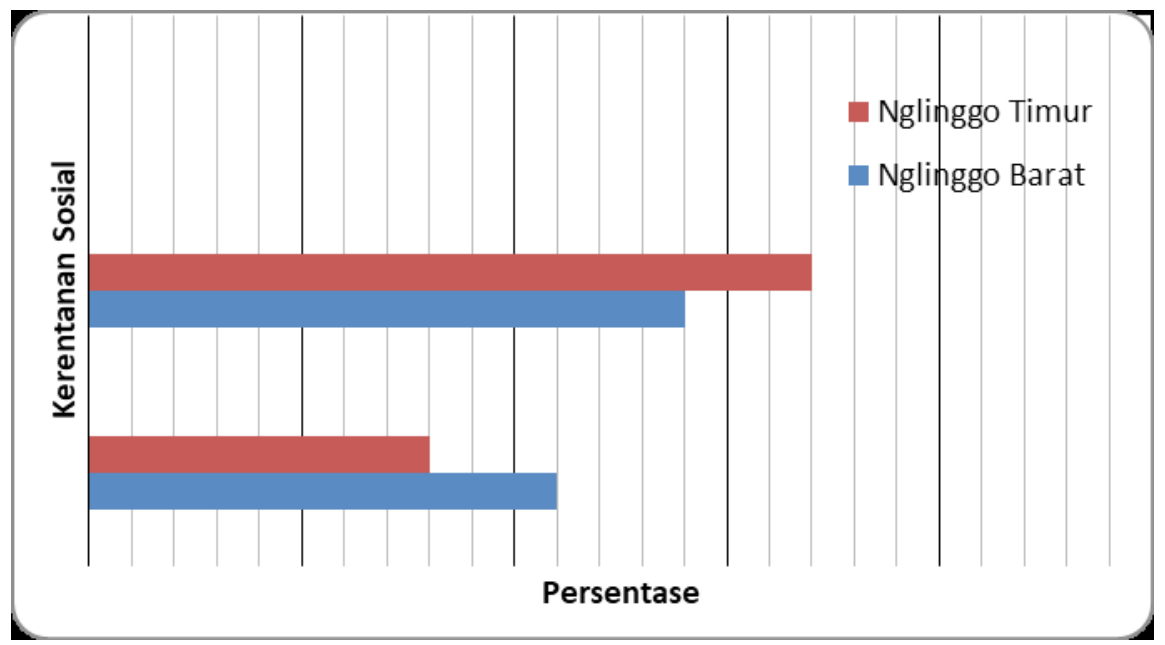

Sumber: Analisis Data Primer 2019

Nglinggo Barat merupakan masyarakat dengan kerentanan sosial sedang dan 44\% merupakan masyarakat dengan kerentanan sosial tinggi. Hasil analisis dari 4 variabel bebas tersebut di Dusun Nglinggo Timur menunjukkan bahwa $68 \%$ merupakan masyarakat dengan kerentanan sosial sedang dan 32\% merupakan masyarakat dengan kerentanan sosial tinggi. Gambar 6 merupakan persentase kerentanan sosial masyarakat di Dusun Nglinggo Barat dan Nglinggo Timur.

\section{Kerentanan Ekonomi Masyarakat}

Kerentan ekonomi masyarakat merupakan variabel terikat yang diperoleh dari 3 variabel bebas. Variabel bebas tersebut terdiri dari sumber penghidupan, tingkat pendapatan, dan tingkat pemenuhan kebutuhan. Sumber penghidupan dalam penelitian ini terdiri dari: kerentanan kelas rendah yakni suami dan istri bekerja dalam sektor penghidupan yang berbeda; kerentanan kelas sedang yakni suami dan istri bekerja, namun masih 
Dina Ruslanjari, Resi Sadewa Permana, Fatimah Wardhana -- Kondisi Kerentanan dan Ketahanan Masyarakat Terhadap Bencana Tanah Longsor di Desa Pagerharjo, Kecamatan Samigaluh, Kabupaten Kulonprogo, Yogyakarta

dalam satu sektor penghidupan yang sama; dan kerentanan kelas tinggi yakni pekerjaan tunggal atau hanya salah satu dari suami atau istri yang bekerja.

Hasil analisis kuesioner penelitian mengenai sumber penghidupan di Dusun Nglinggo Barat menunjukkan bahwa 24\% sumber penghidupan berasal dari suami dan istri yang bekerja dalam sektor berbeda, 56\% berasal dari suami dan istri yang bekerja dalam satu sektor, dan $20 \%$ berasal dari satu sumber penghidupan. Hasil analisis kuesioner penelitian di Dusun Nglinggo Timur menunjukkan bahwa 23\% sumber penghidupan berasal dari suami dan istri yang bekerja dalam sektor berbeda, $54 \%$ berasal dari suami dan istri yang bekerja dalam satu sektor, dan $23 \%$ berasal dari satu sumber penghidupan. Gambar 7 merupakan persentase sumber penghidupan masyarakat di Dusun Nglinggo Barat dan Nglinggo Timur.

Tingkat pendapatan dalam penelitian ini terdiri dari: kerentanan kelas rendah yakni pendapatan lebih dari satu setengah kali UMK; kerentanan kelas sedang yakni pendapatan berkisar antara lebih dari atausama dengan UMK hingga satu setengah kali UMK; dan kerentanan kelas tinggi yakni pendapatan kurang dari Upah Minimum Kabupaten (UMK). Hasil analisis kuesioner penelitian mengenai tingkat pendapatan di Dusun Nglinggo Barat menunjukkan bahwa $8 \%$ masyarakat mempunyai tingkat pendapatan lebih dari satu setengah kali UMK, 24\% masyarakat mempunyai tingkat pendapatan sesuai UMK hingga satu setengah kali UMK, dan 68\% masyarakat mempunyai tingkat pendapatan kurang dari UMK. Hasil analisis kuesioner penelitian di Dusun Nglinggo Timur menunjukkan bahwa 5\% masyarakat mempunyai tingkat pendapatan lebih dari satu setengah kali UMK, 18\% masyarakat mempunyai tingkat pendapatan sesuai UMK hingga satu setengah kali UMK, dan 77\% masyarakat mempunyai tingkat pendapatan kurang dari UMK. Gambar 8 menunjukkan persentase tingkat pendapatan di Dusun Nglinggo Barat dan Nglinggo Timur.

Tingkat pemenuhan kebutuhan dalam penelitian ini terdiri dari: kerentanan kelas rendah yakni baik; kerentanan kelas sedang yakni cukup; dan kerentanan kelas tinggi yakni kurang. Hasil analisis kuesioner penelitian mengenai tingkat pemenuhan kebutuhan di Dusun Nglinggo Barat menunjukkan bahwa $88 \%$ masyarakat mempunyai tingkat

Gambar 7

Presentase Sumber Penghidupan Masyarakat

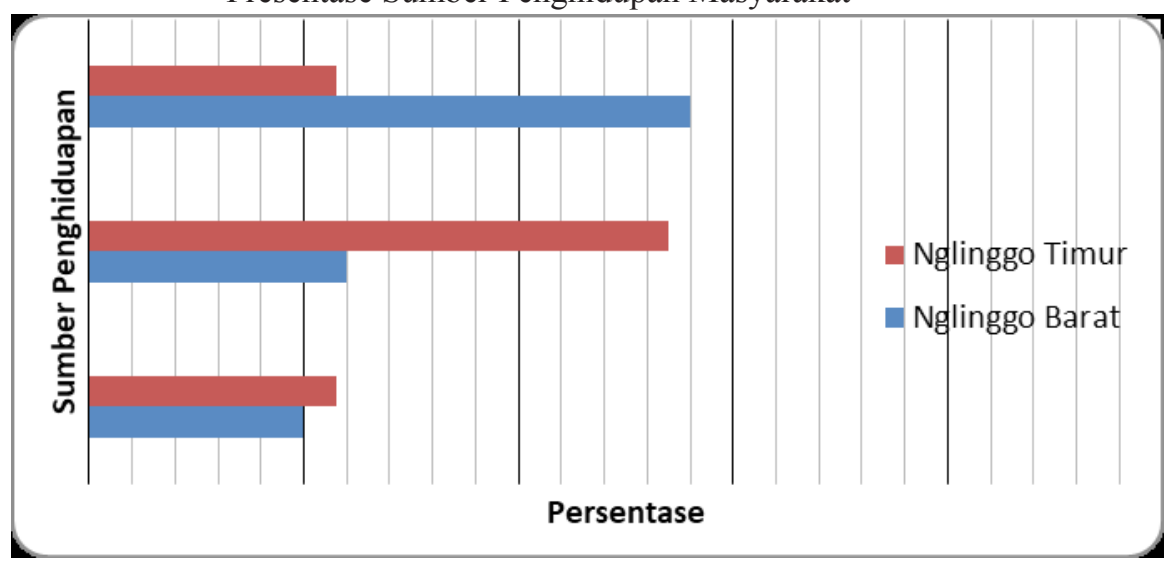

Sumber: Analisis Data Primer 2019 
Gambar 8

Presentase Tingkat Pendapatan Masyarakat

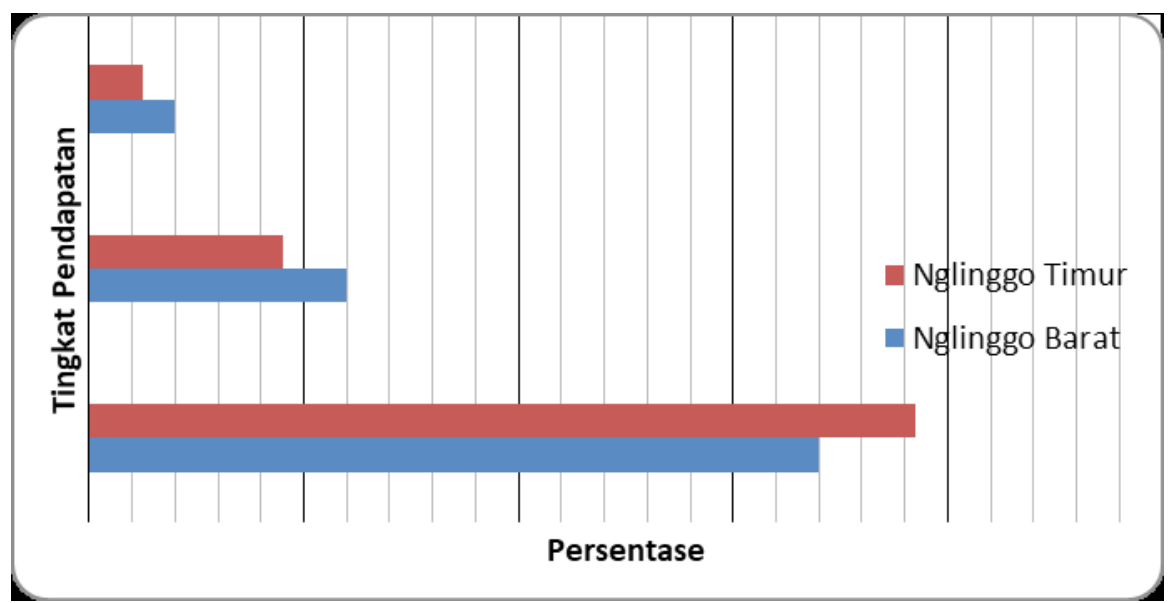

Sumber: Analisis Data Primer 2019

Gambar 9

Presentase Tingkat Pemenuhan Kebutuhan

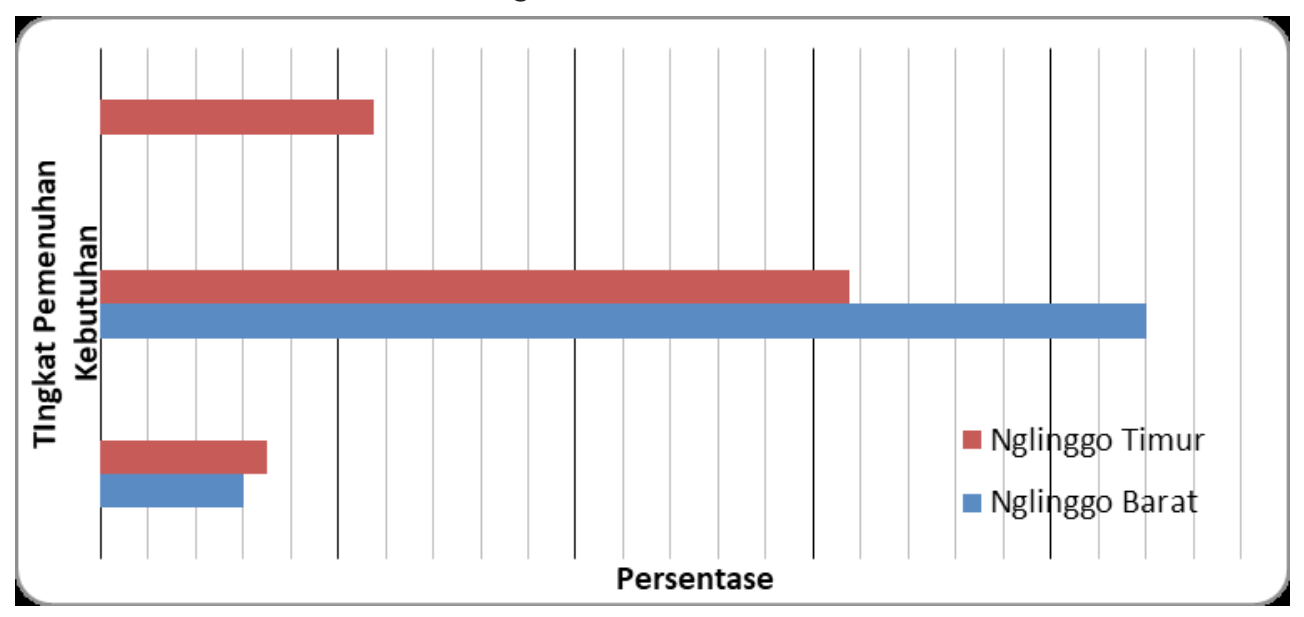

Sumber: Analisis Data Primer 2019

pemenuhan kebutuhan cukup dan $12 \%$ masyarakat mempunyai tingkat pemenuhan kebutuhan kurang. Hasil analisis kuesioner penelitian di Dusun Nglinggo Timur menunjukkan bahwa $23 \%$ masyarakat mempunyai tingkat pemenuhan kebutuhan baik, 63\% masyarakat mempunyai tingkat pemenuhan kebutuhan cukup, dan 14\% masyarakat mempunyai tingkat pemenuhan kebutuhan kurang. Gambar 9 menunjukkan persentase tingkat pemenuhan kebutuhan di Dusun Nglinggo Barat dan Nglinggo Timur.
Berdasarkan hasil dari analisis dari sumber penghidupan, tingkat pendapatan, dan tingkat pemenuhan kebutuhan, diketahui bahwa 56\% masyarakat Dusun Nglinggo Barat merupakan masyarakat dengan kerentanan ekonomi sedang dan $44 \%$ masyarakat merupakan masyarakat dengan kerentanan ekonomi tinggi. Hasil analisis dari 3 variabel bebas tersebut di Dusun Nglinggo Timur menunjukkan bahwa $77 \%$ masyarakat merupakan masyarakat dengan kerentanan ekonomi sedang dan 23\% 
Dina Ruslanjari, Resi Sadewa Permana, Fatimah Wardhana -- Kondisi Kerentanan dan Ketahanan Masyarakat Terhadap Bencana Tanah Longsor di Desa Pagerharjo, Kecamatan Samigaluh, Kabupaten Kulonprogo, Yogyakarta

masyarakat merupakan masyarakat dengan kerentanan ekonomi tinggi. Persentase kerentanan ekonomi masyarakat di Dusun Nglinggo Barat dan Nglinggo Timur dapat dilihat pada Gambar 10.

\section{Kerentanan Fisik Masyarakat}

Kerentanan Kerentan fisik masyarakat merupakan variabel terikat yang diperoleh dari 2 variabel bebas. Variabel bebas tersebut terdiri dari material rumah dan keberadaan halaman rumah. Material rumah dalam penelitian ini terdiri dari: kerentanan kelas rendah yakni material rumah dari bahan permanen; kerentanan kelas sedang yakni material rumah dari bahan semi permanen; dan kerentanan kelas tinggi yakni material rumah dari bahan tidak permanen. Hasil analisis kuesioner penelitian mengenai material rumah di Dusun Nglinggo Barat menunjukkan bahwa 16\% material rumah dari bahan permanen, 56\% material rumah dari bahan semi permanen,

Gambar 10

Presentase Kerentanan Ekonomi Masyarakat

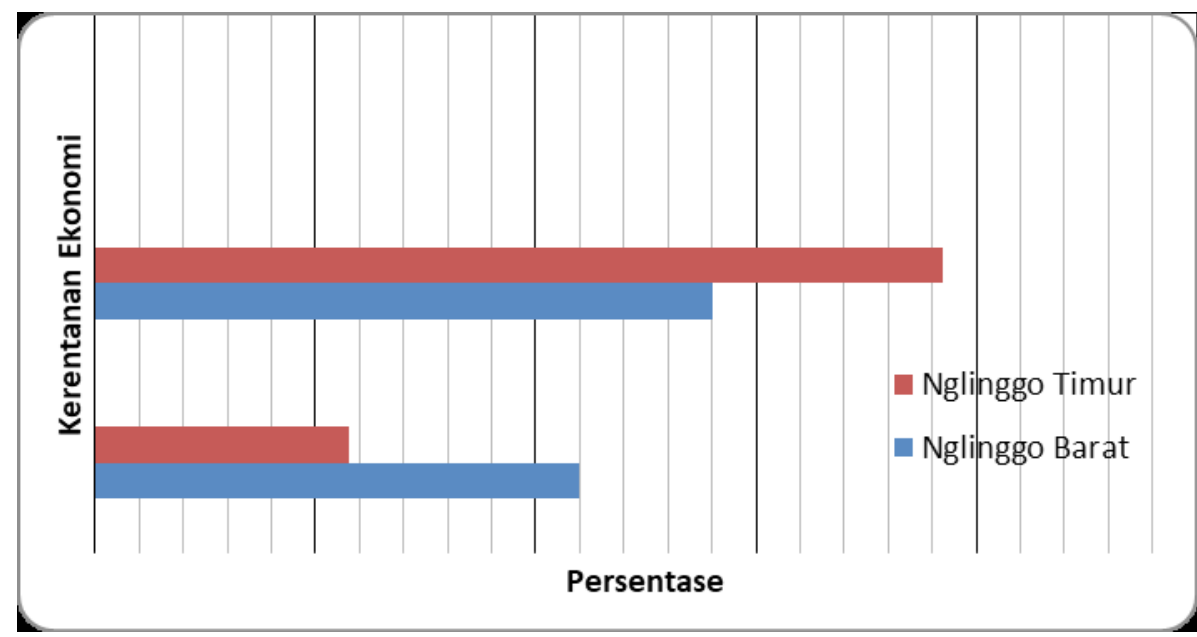

Sumber: Analisis Data Primer 2019

Gambar 11

Persentase Material Rumah

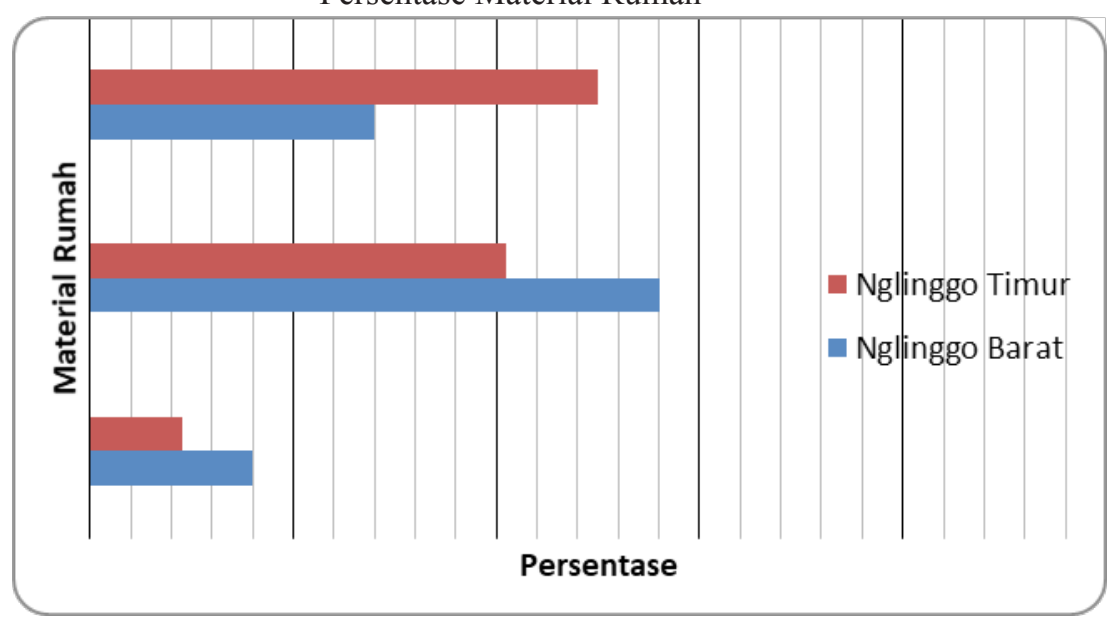

Sumber: Analisis Data Primer 2019 
dan $28 \%$ material rumah dari bahan tidak permanen. Hasil analisis kuesioner penelitian mengenai material rumah di Dusun Nglinggo Timur menunjukkan bahwa 50\% material rumah dari bahan permanen, $41 \%$ material rumah dari bahan semi permanen, dan 9\% material rumah dari bahan tidak permanen. Persentase material rumah di Dusun Nglinggo Barat dan Nglinggo Timur dapat dilihat pada Gambar 11.

Keberadaan halaman rumah dalam penelitian ini menunjukkan kelas kerentanan sebagai berikut: kerentanankelas rendah yakni mempunyai halaman rumah dengan jarak lebih dari 1 kali tinggi rumah; kerentanankelas sedang yakni mempunyai halaman rumah dengan jarak kurang dari 1 (satu) kali tinggi rumah; dan kerentanan kelas tinggi yakni tidak ada halaman rumah. Hasil analisis kuesioner penelitian mengenai keberadaan halaman rumah di Dusun Nglinggo Barat menunjukkan bahwa 4\% mempunyai halaman rumah dengan jarak lebih dari 1 kali tinggi rumah, $56 \%$ mempunyai halaman rumah dengan jarak kurang dari 1 kali tinggi rumah, dan 40 $\%$ tidak ada halaman rumah. Hasil analisis kuesioner penelitian mengenai material rumah di Dusun Nglinggo Timur menunjukkan bahwa $45 \%$ mempunyai halaman rumah dengan jarak lebih dari 1 kali tinggi rumah, $50 \%$ mempunyai halaman rumah dengan jarak kurang dari 1 kali tinggi rumah, dan 5\% tidak ada halaman rumah. Gambar 12 merupakan persentase keberadaan halaman rumah di Dusun Nglinggo Barat dan Nglinggo Timur.

Hasil analisis material rumah dan keberadaan halaman rumah menunjukkan bahwa $60 \%$ masyarakat Dusun Nglinggo Barat adalah masyarakat dengan kerentanan fisik sedang dan 40\% merupakan masyarakat dengan kerentanan fisik tinggi.Hasil analisis dari 3 variabel bebas tersebut di Dusun Nglinggo Timur menunjukkan bahwa $77 \%$ merupakan masyarakat dengan kerentanan fisik sedang dan 23\% masyarakat merupakan masyarakat dengan kerentanan fisik tinggi. Persentase kerentanan fisik masyarakat di Dusun Nglinggo Barat dan Nglinggo Timur dapat dilihat pada Gambar 13.

\section{Kerentanan Lingkungan Masyarakat}

Kerentan lingkungan masyarakat merupakan variabel terikat yang diperoleh dari 2 variabel bebas. Variabel bebas tersebut terdiri dari keberadaan penahan tebing dan kondisi jalur evakuasi. Keberadaan penahan

Gambar 12.

Persentase Keberadaan Halaman Rumah

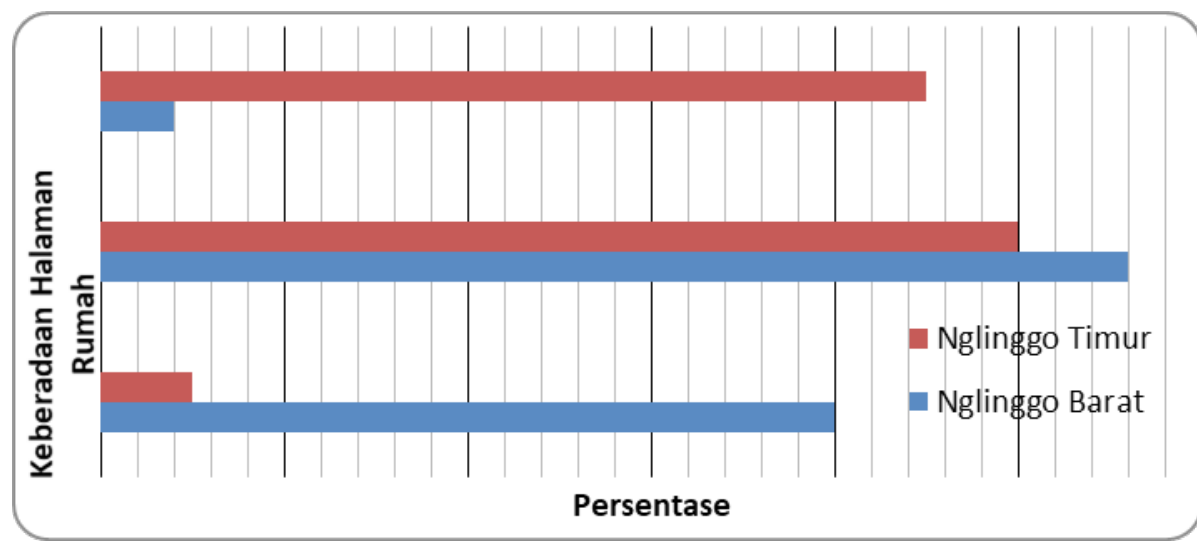

Sumber: Analisis Data Primer 2019 
Dina Ruslanjari, Resi Sadewa Permana, Fatimah Wardhana -- Kondisi Kerentanan dan Ketahanan Masyarakat Terhadap Bencana Tanah Longsor di Desa Pagerharjo, Kecamatan Samigaluh,

Kabupaten Kulonprogo, Yogyakarta

Gambar 13

Persentase Kerentanan Fisik Masyarakat

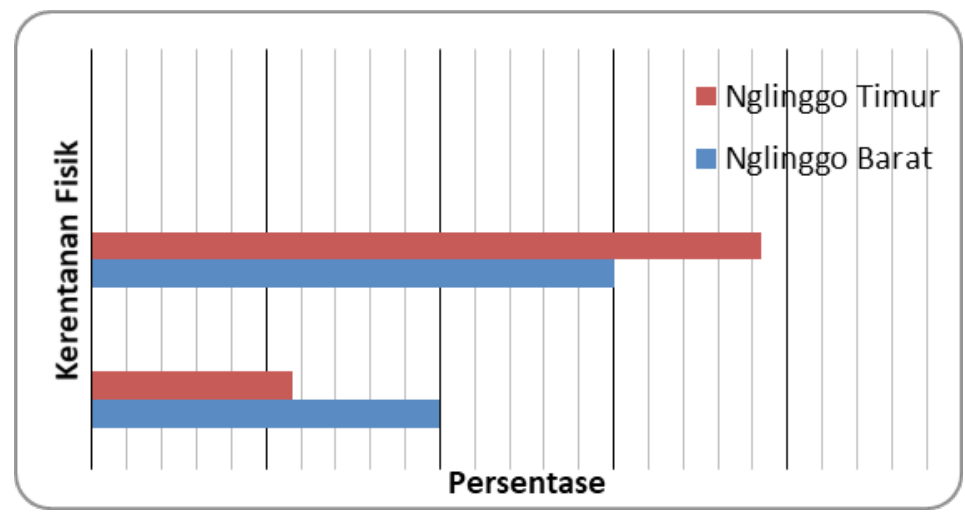

Sumber: Analisis Data Primer 2019

Gambar 14

Persentase Keberadaan Penahan Tebing

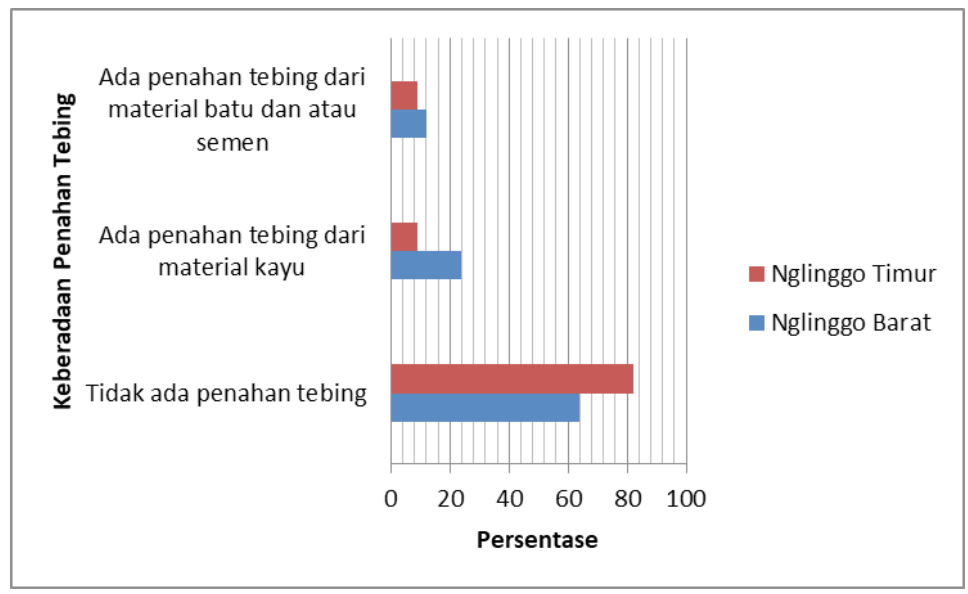

Sumber: Analisis Data Primer 2019

tebing dalam penelitian ini terdiri dari: kerentanan kelas rendah yakni penahan tebing dari material permanen seperti batu dan semen; kerentanan kelas sedang yakni penahan tebing dari material tidak permanen seperti kayu atau bambu; dan kerentanan kelas tinggi yakni tidak ada penahan tebing. Hasil analisis kuesioner penelitian mengenai keberadaan penahan tebing di Dusun Nglinggo Barat menunjukkan bahwa $12 \%$ penahan tebing terbuat dari batu dan atau semen, $24 \%$ penahan tebing dari material kayu, dan $64 \%$ tidak ada penahan tebing. Hasil analisis kuesioner penelitian mengenai keberadaan penahan tebing di Dusun Nglinggo Timur menunjukkan bahwa 9\% penahan tebing terbuat dari batu dan atau semen, $9 \%$ penahan tebing dari material kayu, dan $82 \%$ tidak ada penahan tebing. Gambar 14 merupakan persentase keberadaan penahan tebing di Dusun Nglinggo Barat dan Nglinggo Timur.

Kondisi jalur evakuasi dalam penelitian ini merupakan variabel bebas penentu kerentanan lingkungan yang diperoleh berdasarkan tiga faktor penentu kondisi jalur evakuasi, yakni kedekatan dengan tebing, lebar jalan, dan kondisi jalan. Klasifikasi kondisi jalur evakuasi terdiri dari: kerentanan 
kelas rendah yakni baik; kerentanan kelas sedang yakni cukup; dan kerentanan kelas tinggi yakni kurang. Hasil analisis kuesioner penelitian mengenai kondisi jalur evakuasi di Dusun Nglinggo Barat menunjukkan bahwa 36\% kondisi jalur evakuasi yang cukup dan $64 \%$ kondisi jalur evakuasi yang kurang. Hasil analisis kuesioner penelitian di Dusun Nglinggo Timur Menunjukkan bahwa $50 \%$ kondisi jalur evakuasi yang cukup dan $50 \%$ m kondisi jalur evakuasi yang kurang. Gambar 15 merupakan persentase kondisi jalur evakuasi di Dusun Nglinggo Barat dan Nglinggo Timur.
Berdasarkan hasil dari analisis dari keberadaan penahan tebing dan kondisi jalur evakuasi, diketahui bahwa 24\% masyarakat Dusun Nglinggo Barat merupakan masyarakat dengan kerentanan lingkungan sedang dan 76\% merupakan masyarakat dengan kerentanan lingkungan tinggi. Hasil analisis dari 2 variabel bebas tersebut di Dusun Nglinggo Timur menunjukkan bahwa 32\% merupakan masyarakat dengan kerentanan lingkungan sedang dan $68 \%$ merupakan masyarakat dengan kerentanan lingkungan tinggi. Gambar 16 merupakan persentase

Gambar 15

Persentase Kondisi Jalur Evakuasi

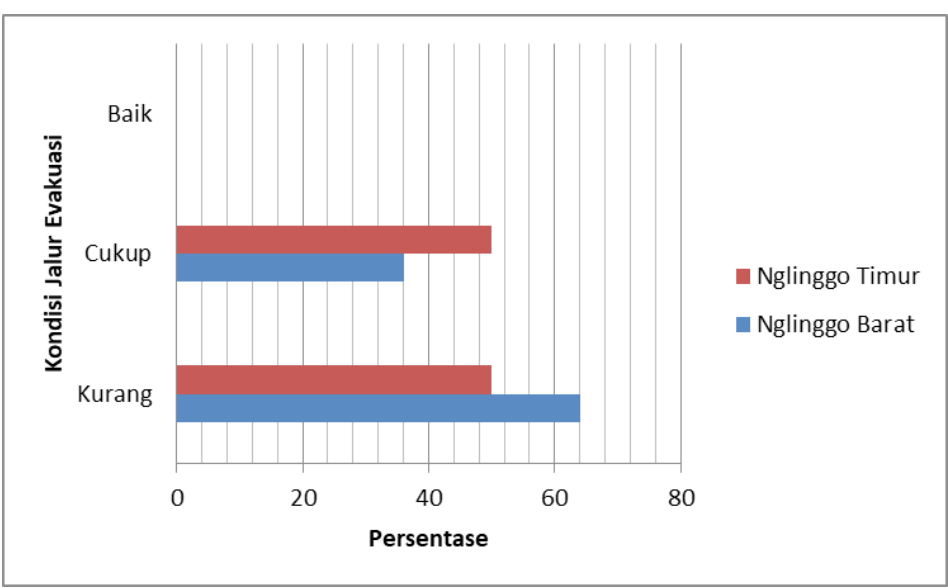

Sumber: Analisis Data Primer 2019

Gambar 16

Persentase Kerentanan Lingkungan Masyarakat

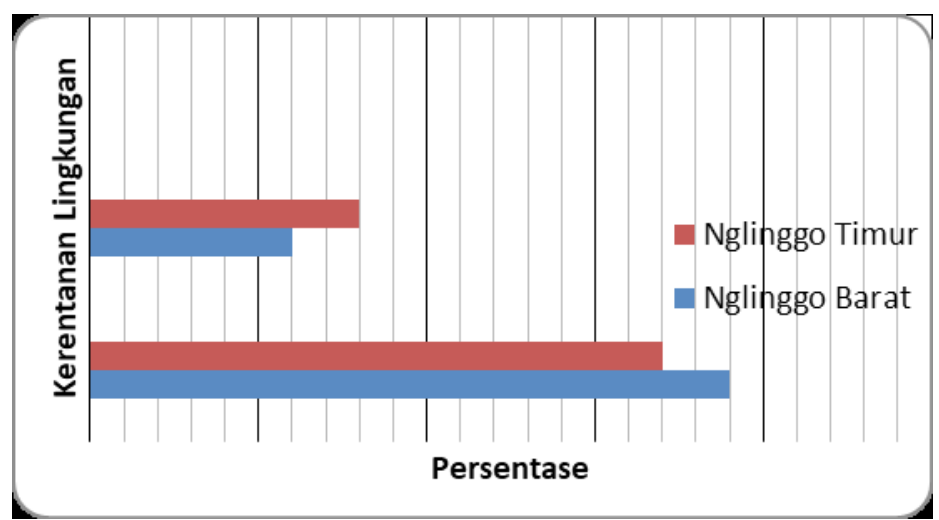

Sumber: Analisis Data Primer 2019 
Dina Ruslanjari, Resi Sadewa Permana, Fatimah Wardhana -- Kondisi Kerentanan dan Ketahanan Masyarakat Terhadap Bencana Tanah Longsor di Desa Pagerharjo, Kecamatan Samigaluh, Kabupaten Kulonprogo, Yogyakarta

kerentanan lingkungan masyarakat di Dusun Nglinggo Barat dan Nglinggo Timur.

\section{Kerentanan Masyarakat di Dusun Nglinggo Barat dan Nglinggo Timur}

Penilaian kerentanan dilakukan berdasarkan pengolahan dari hasil analisis dari 4 variabel bebas. Variabel bebas tersebut terdiri atas kerentanan sosial, kerentanan ekonomi, kerentanan fisik, dan kerentanan lingkungan. Menurut Vogel dan O'Brien (2004); Lummen dan Yamada, 2014), kerentanan memiliki multidimensi aspek (seperti: fisik, sosial, ekonomi, lingkungan, kelembagaan dan faktor manusia menentukan kerentanan). Berdasarkan hasil analisis dari 4 variabel bebas, 28\% masyarakat Dusun Nglinggo Barat merupakan masyarakat dengan kerentanan masyarakat sedang dan $72 \%$ merupakan masyarakat dengan kerentanan masyarakat tinggi. Berdasarkan persentase kerentanan masyarakat tersebut, kerentanan masyarakat terhadap bencana tanah longsor di Dusun Nglinggo Barat secara total dapat dikatagorikan ke dalam kerentanan masyarakat tinggi.

Hasil analisis dari 4 variabel bebas di Dusun Nglinggo Timur menunjukkan bahwa 32\% merupakan masyarakat dengan kerentanan masyarakat sedang dan $68 \%$ merupakan masyarakat dengan kerentanan masyarakat tinggi. Berdasarkan persentase kerentanan masyarakat tersebut, kerentanan masyarakat terhadap bencana tanah longsor di Dusun Nglinggo Timur secara total dapat dikategorikan ke dalam kerentanan masyarakat tinggi. Gambar 17 merupakan persentase kerentanan masyarakat terhadap bencana tanah longsor di Dusun Nglinggo Barat dan Nglinggo Timur.

\section{Ketahanan Masyarakat terhadap Tanah Longsor}

Berdasarkan nilai analisis kerentanan terhadap tanah longsor di Dusun Nglinggo Timur dan Nglinggo Barat, terdapat kesamaan tingkat pada kerentanan sosial, ekonomi dan fisik masyarakat di kedua dusun tersebut. Terdapat lebih dari 50\% masyarakat di Dusun Nglinggo Timur maupun Nglinggo Barat termasuk ke dalam kategori kerentanan tinggi. Tingkat kerentanan masyarakat terhadap bencana berbanding terbalik dengan tingkat kapasitas atau ketahanan masyarakat terhadap bencana. UNISDR (2004) dan Thywissen

Gambar 17

Persentase Kerentanan Masyarakat terhadap Bencana Tanah Longsor

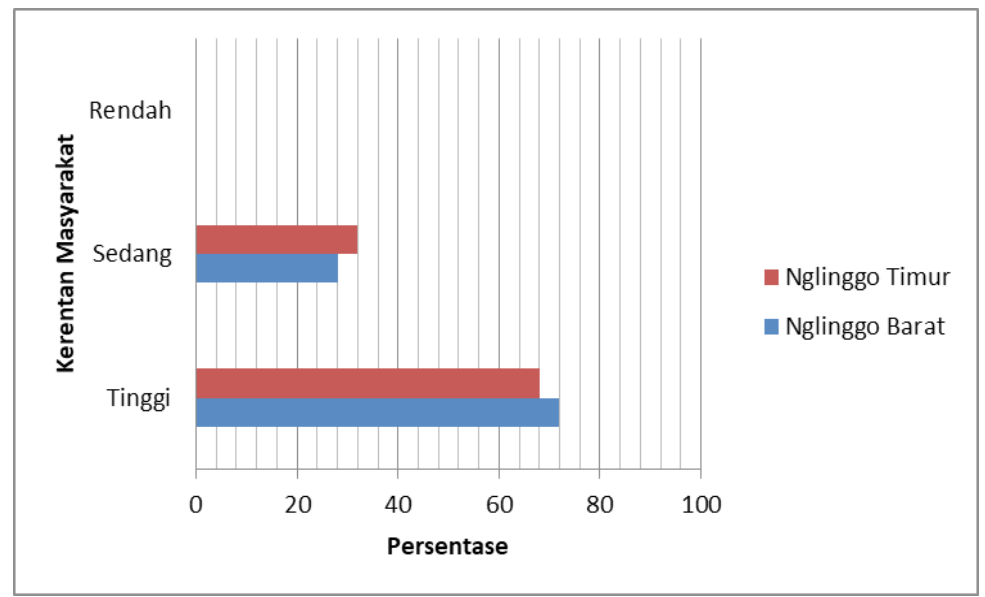

Sumber: Analisis Data Primer 2019 
(2006) merumuskan kapasitas (capacity) sebagai kombinasi dari kumpulan kekuatan, dan sumberdaya yang tersedia dari suatu komunitas, masyarakat atau organisasi yang dapat mengurangi tingkat risiko bencana.

Berdasarkan hasil analisis kerentanan masyarakat di kedua dusun tersebut, menunjukkan bahwa kapasitas atau ketahanan masyarakatnya terhadap tanah longsor adalah rendah. Daerah dengan ancaman bencana tinggi, kapasitas atau ketahanan masyarakatnya rendah, hasil penelitian ini juga didukung oleh temuan penelitian yang dilakukan oleh Wayan (2015). Upaya untuk meningkatkan ketahanan masyarakat kedua dusun tersebut untuk menurunkan risiko dan kerentanannya terhadap bencana tanah longsor salah satunya dengan peningkatan pendidikan. Sejalan dengan Samir (2013) bahwa dengan investasi dalam pendidikan dapat untuk menurunkan kerentanan komunitas terhadap banjir dan tanah longsor di masa depan dan efek ini bisa melampaui kerentanan terhadap jenis bencana alam lainnya.

Penilaian ketahanan masyarakat dilakukan dengan menganalisis ketahanan sosial, ketahanan ekonomi, ketahanan fisik dan ketahanan lingkungan berdasarkan data yang sama dengan penilaian kerentanan masyarakat di Dusun Nglinggo Barat dan Nglinggo Timur. Nilai ketahanan atau kapasitas sebagai berikut ini.

Pertama, sebanyak 28\% masyarakat di Dusun Nglinggo Barat termasuk masyarakat dengan ketahanan sedang, dan 72\% masyarakat lainnya termasuk masyarakat dengan tingkat ketahanan yang rendah terhadap bencana tanah longsor, Kedua, dusun Nglinggo Timur, terdapat sebanyak 32\% masyarakat dengan tingkat ketahanan sedang dan 68\% lainnya termasuk ke dalam masyarakat dengan tingkat ketahanan yang rendah terhadap bencana tanah longsor.

\section{SIMPULAN}

Berdasarkan hasil penelitian yang telah dilakukan mengenai kerentanan masyarakat terhadap bencana tanah longsor di Dusun Nglinggo Barat dan Nglinggo Timur, maka dapat ditarik kesimpulan sebagai berikut ini.

Pertama, dusun Nglinggo Barat dan Dusun Glinggo Timur: lebih dari separuh masyarakatnya mempunyai kerentanan sosial kategori sedang; kerentanan ekonomi kategori sedang; kerentanan fisik kategori sedang, dan; kerentanan lingkungan kategori tinggi.

Kedua, lebih dari separuh masyarakat di Dusun Nglinggo Baratdan Dusun Nglinggo Timur termasuk kategori kerentanan tinggi, hal ini dibuktikan dengan: (a) di Dusun Nglinggo Barat; sebanyak 72\% termasuk kerentanan masyarakat kategori tinggi, dan (b) di Dusun Nglinggo Timur; sebanyak 68\% termasuk kerentanan masyarakat kategori tinggi.

Ketiga, kondisi ketahanan masyarakat terhadap bencanatanah longsor di kedua dusun berdasarkan analisis ketahanan sosial, ekonomi, fisik dan lingkungan menunjukkan tingkat ketahanan masyarakat yang masih rendah. Di Dusun Nglinggo Barat terdapat $72 \%$ masyarakat dengan tingkat ketahanan rendah dan di Dusun Nglinggo Timur terdapat $68 \%$ masyarakat dengan tingkat ketahanan rendah.

\section{DAFTAR PUSTAKA}

Badan Nasional Penanggulangan Bencana (BNPB), 2019, Data dan Informasi Bencana Indonesia, BNPB. Diakses dari <http://bnpb.cloud/dibi/>pada 23 Desember 2019. 
Dina Ruslanjari, Resi Sadewa Permana, Fatimah Wardhana -- Kondisi Kerentanan dan Ketahanan Masyarakat Terhadap Bencana Tanah Longsor di Desa Pagerharjo, Kecamatan Samigaluh, Kabupaten Kulonprogo, Yogyakarta

Hadmoko, D.S., Lavigne, F., Sartohadi, J., Hadi, P., dan Winaryo, 2010, "Landslide Hazard and Risk Assessment and Their Application in Risk Management and Landuse Planning in Eastern Flank of Menorah Mountains, Yogyakarta Province, Indonesia", Natural Hazard(2010) 54:623-642.

Hardiyatmo, H.C, 2012, Tanah Longsor dan Erosi: Kejadian dan Penanganan, Yogyakarta: Gadjah Mada University Press.

KC, Samir., 2013. 'Community Vulnerability to Floods and Landslides in Nepal', Ecology and Society, vol. 18, no. 1.

Kumar R.,2005, Research Metodologi: A Step by Steo Guide for Beginners, Second Edition', Malaysia: Sage Publications Ltd. Lummen and Yamada, 2014, Implementation of an Integrated Vulnerability and Risk Assessment Model, Nat Hazards (2014) 73:1085-1117

Nazir M., 2013, Metode Penelitian, Bogor: Penerbit Ghalia Indonesia.

Notoatmodjo dan Soekidjo, 2002, Metodologi

Penelitian Kesehatan, Jakarta: Rineka Cipta.

Riyanto, E.A., 2015, Analisis Tingkat Kerentanan Sosial Ekonomi dan Pengetahuan Dalam Mengelola Bencana Erupsi Gunung Merapi di Kecamatan Cangkringan Kabupaten Sleman, Yogyakarta: Tesis, Sekolah Pascasarjana, Universitas Gadjah Mada. Sofhani, T.F, 2016. Community Resilience (Ketahanan Masyarakat) Menghadapi Bencana, University of Hawai'I dan Institut Teknologi Bandung.

Sugiyono,2013, Metode Penelitian Kuantitatif, Kualitatif, dan Kombinasi (Mixed Methods), Bandung: Penerbit Alfabeta.
Thywissen, 2006, Components of Risk, A Comparative Glossary, Bonn: United Nations University Institute for Environment and Human Security.

Twigg J., 2007.Characteristics of a Disasterresilient Community. Bangladesh: for the DFID Disaster Risk Reduction Interagency Coordination Group.

UNISDR 2004, Living with Risk: A global review of disaster reduction initiatives, Geneva, Switzerland: United Nations Inter-Agency Secretariat of the International Strategy for Disaster Reduction UN/ISDR).

UNU,2004, Comparative Glossary for Core Terms of Disaster Reduction, Germany: United Nations University, Institute for Environment and Human Security.

Van Westen C.J., Alkema D., Damen M.C.J., Kerle N., dan Kingma, N.C., 2011, Multi-hazard RiskAssessment: Distance Education Course, Guide Book, United Nations - ITC School on Disaster Geoinformation Management.

Wayan, I. 2015. Analisis Risiko Bencana Tanah Longsor Di Kecamatan Sukasada, Kabupaten Buleleng: Tesis, Program Studi Ilmu Lingkungan, Udayana.

Perundangan

Anonim,2012a, Peraturan Kepala Badan Nasional Penanggulangan Bencana (BNPB) Nomor 2 Tahun 2012 tentang Pedoman Umum Pengkajian Risiko Bencana, Jakarta: BNPB.

Anonim,2012b, Peraturan Kepala Badan Nasional Penanggulangan Bencana (BNPB) Nomor 3 Tahun 2012 tentang Panduan Penilaian Kapasitas Daerah dalam Penanggulangan Bencana, Jakarta: BNPB. 